\title{
IMMUNOGENICITY OF SLOWLY SEDIMENTING ANTIGEN OF JAPANESE ENCEPHALITIS VIRUS ENVELOPE GLYCOPROTEIN ISOLATED FROM INFECTED CULTURE FLUIDS
}

\author{
Golam Masud Mohammad Shameem
}

Received July 12 1991/Accepted September 21991

\begin{abstract}
Slowly sedimenting antigen (SE) and the rapidly sedimenting antigen $(\mathrm{RE})$, associated with envelope glycoprotein $\mathrm{E}$ were prepared from the concentrated infected culture fluids of Japanese encephalitis (JE) virus. Mice were immunized by each antigen before and after inactivation of virus infectivity by ultraviolet (UV) irradiation. The immunogenicity of the antigens determined by the plaque reduction neutralization test (PRNT), indirect ELISA and hemagglutination-inhibition (HI) test, indicated that SE was almost equally immunogenic as RE, and that the PRNT epitopes on both antigens were more immunogenic before $\mathrm{UV}$-inactivation than after the inactivation.
\end{abstract}

\section{INTRODUCTION}

$\mathrm{JE}$ is an acute viral encephalitis and is a serious public health problem in many Asian countries (Umenai et al., 1985). The etiologic agent, JE virus, belongs to the Flaviviridae family (Westaway et al., 1985) comprising about 70 viruses (Calisher et al., 1989), of which many are pathogens for humans and domestic animals (Monath, 1986). Current JE vaccine has been developed as formalin-inactivated and highly purified virion from infected mouse brains and has successfully been used for JE control in Japan, Republic of Korea, and some other countries (Hammon et al., 1971; Huang, 1982; Oya, 1988; Igarashi, 1988). Besides rapidly sedimenting virus antigens associated with complete virion, slowly sedimenting hemagglutinin or soluble complement-fixing antigen (SCF) of flaviviruses have been described in the infected mouse brain homogenates or in culture fluids by sucrose gradient sedimentation (Igarashi et al., 1963; Kitaoka and Nishimura, 1965; Smith et al., 1970; Shameem et al., 1989). However the immunogenicity of SE has not well been documented. In order to clarify the immunogenicity of $\mathrm{SE}$ and $\mathrm{RE}$, we examined anti-JE titer of the sera from mice immunized with SE or RE before and after UV-inactivation.

\section{Materials AND Methods}

\section{Cells and virus}

Aedes albopictus, clone $\mathrm{C} 6 / 36$, cells (Igarashi, 1978) were grown at $28^{\circ} \mathrm{C}$ and $\mathrm{BHK} 21$ cells

Department of Virology, Institute of Tropical Medicine, Nagasaki University,

12-4 Sakamoto-machi, Nagasaki 852, Japan 
at $37^{\circ} \mathrm{C}$ in Roux bottles with $750 \mathrm{~cm}^{3}$ volume. The cell growth medium was Eagle's minimum essential medium supplemented with $0.2 \mathrm{mmol} / l$ each of 7 nonessential amino acids (Eagle, 1959) and $10 \%$ heat-inactivated fetal calf serum (FCS). The origin of a wild strain JE virus, JaOArS982, was described by Hori et al. (1986), and seed virus was prepared in C6/36 cells at $28^{\circ} \mathrm{C}$.

\section{Preparation of slowly sedimenting and rapidly sedimenting antigens of JE virus}

The SE and RE were isolated by sucrose gradient sedimentation of concentrated infected culture fluids as described in our previous communication (Shameem et al., 1989). In this experiment specimens were harvested $36 \mathrm{hr}$ after infection for both cell lines, but incubated at $28^{\circ} \mathrm{C}$ for $\mathrm{C} 6 / 36$ and $37^{\circ} \mathrm{C}$ for $\mathrm{BHK} 21$ cells, respectively.

\section{Inactivation of the infective virus by $\mathrm{UV}$-irradiation}

Immunogens $(2.5 \mathrm{~m} l)$ were spread on a petri dish $(60 \mathrm{~mm})$ and exposed to $2 \mathrm{UV}$ bulbs $(20 \mathrm{~W})$ at a distance of $42 \mathrm{~cm}$ for 5 minutes. After the exposure, infectivity of the virus was undetectable (Sachiko Matsuo, personal communication).

\section{Immunization of mice}

BALB / c mice were immunized by 4 intraperitoneal injections at 1 week interval $(0.1 \mathrm{ml} /$ mouse/dose), using either UV irradiated or unirradiated SE and/or RE fractions, which were mixed with an equal volume of Freund's complete adjuvant for the first injection or incomplete adjuvant for the subsequent injections. One week after the last injection, mice were individually bled and serum was separated for further test.

\section{Plaque reduction neutralization test (PRNT or $\mathrm{N}$ )}

This procedure was carried out as described by Hashimoto et al. (1971) with some modification. Serial two fold serum dilutions beginning from 1:10 were made using the diluent of 5\% FCS in Eagle's medium and mixed with an equal volume of the seed virus diluted to yield $100-200 \mathrm{PFU} / 0.1 \mathrm{~m} l$. For virus control the working dilution of the virus was mixed with an equal volume of the diluent. The mixtures were incubated for $90 \mathrm{~min}$ at $37^{\circ} \mathrm{C}$ in humidified atmosphere containing $5 \% \mathrm{CO}_{2}$. At the end of the incubation, the mixture was inoculated to the monolayer of BHK21 cells $(0.1 \mathrm{ml} /$ well $)$ grown on 24-well polystyrene tissue culture plate. Adsorption was carried out at $37^{\circ} \mathrm{C}$ for $2 \mathrm{hr}$ and the cells were covered with $1.25 \%$ methyl cellulose in the maintenance medium (cell growth medium from which serum concentration was reduced to $2 \%$ ). Plates were incubated for 5 days in the same condition as above and cells were fixed with cold methanol, stained with $0.1 \%$ trypan blue in $0.9 \% \mathrm{NaCl}$ at room temperature for $1 \mathrm{hr}$ to reveal the plaques. The $\mathrm{N}$ was scored as positive when more than $50 \%$ plaque reduction was observed compared with the negative control of virus-diluent mixture. Reciprocal of the highest dilution of the test serum with positive plaque reduction was considered as $\mathrm{N}$ titer.

\section{Sandwich ELISA}

The modified procedure of Voller et al. (1976) was described in our previous communication (Shameem et al., 1989). 


\section{Indirect micro ELISA}

This was carried out according to Voller et al. (1976) using purified JE antigen (100 $\mu \mathrm{g} /$ $\mathrm{m} l$ ). ELISA titer of test specimens was calculated by comparing the OD with those by serially diluted standard positive serum as described before (Igarashi et al., 1981; Morita et $a l ., 1982)$. Standard anti-JE mouse serum was prepared by repeated intraperitoneal inoculation of purified JE virus (Srivastava et al., 1987).

\section{Hemagglutination-inhibition (HI) test}

The procedure was carried out according to Clarke and Casals (1985) using goose red blood cells in virus adjusting diluent (VAD) at $\mathrm{pH}$ 6.6.

\section{Statistical analysis}

Student's t test was performed according to the standard procedure.

\section{RESUlTS}

\section{Mouse immunogenicity of SE and RE before UV-inactivation}

In the initial experiment, mice were immunized with $\mathrm{SE}$ or $\mathrm{RE}$ fractions of both $\mathrm{C} 6 / 36$ and BHK21 cells without UV-inactivation. The antibody titer of individual serum from immunized mice was shown in Table 1 . When antibody titers raised by $\mathrm{SE}$ and $\mathrm{RE}$ were compared, $\mathrm{SE}$ immunogen from $\mathrm{C} 6 / 36$ cells produced less $\mathrm{N}$ and $\mathrm{HI}$ titers than $\mathrm{RE}$ from the same cells, and these differences were statistically significant (Table 3). While, both SE and

Table 1 Immunogenicity of SE and RE before UV-irradiation, as shown by titers in $\log$ for N, ELISA and $\mathrm{HI}$

\begin{tabular}{|c|c|c|c|c|c|c|c|}
\hline \multirow{2}{*}{$\begin{array}{c}\text { Serum } \\
\text { No. }\end{array}$} & \multirow{2}{*}{ Immunogen } & \multicolumn{2}{|r|}{$\mathrm{N}$} & \multicolumn{2}{|c|}{ ELISA } & \multicolumn{2}{|c|}{$\mathrm{HI}$} \\
\hline & & Titer & Mean & Titer & Mean & Titer & Mean \\
\hline $1-1$ & C6/36 SE & 1.30 & $1.68 \pm 0.29$ & 3.85 & $4.28 \pm 0.40$ & 1.90 & $2.05 \pm 0.31$ \\
\hline $1-2$ & & 1.60 & (GMT 48) & 4.72 & (GMT 19,054) & 1.90 & (GMT 112) \\
\hline $1-3$ & & 1.90 & & 4.04 & & 1.90 & \\
\hline $1-4$ & & 1.90 & & 4.49 & & 2.51 & \\
\hline $2-1$ & $\mathrm{C} 6 / 36 \quad \mathrm{RE}$ & 2.20 & $2.20 \pm 0.25$ & 4.16 & $4.29 \pm 0.24$ & 2.56 & $2.66 \pm 0.30$ \\
\hline $2-2$ & & 2.51 & (GMT 158) & 4.65 & (GMT 19,498) & 2.51 & \\
\hline $2-3$ & & 1.90 & & 4.22 & & 2.51 & \\
\hline $2-4$ & & 2.20 & & 4.14 & & 3.11 & \\
\hline $3-1$ & BHK21 SE & 1.90 & $2.05 \pm 0.21$ & 4.49 & $4.49 \pm 0.01$ & 2.20 & $2.36 \pm 0.22$ \\
\hline $3-2$ & & 2.20 & (GMT 112) & 4.48 & (GMT 30,902) & 2.51 & (GMT 229) \\
\hline $4-1$ & BHK21 RE & 2.20 & $2.08 \pm 0.16$ & 4.06 & $4.22 \pm 0.38$ & 2.81 & $2.69 \pm 0.27$ \\
\hline $4-2$ & & 2.20 & (GMT 120) & 4.48 & (GMT 16,595) & 2.51 & (GMT 490) \\
\hline $4-3$ & & 2.20 & & 4.72 & & 2.51 & \\
\hline $4-4$ & & 1.90 & & 3.89 & & 3.11 & \\
\hline $4-5$ & & 2.20 & & 3.96 & & 2.51 & \\
\hline
\end{tabular}

Note: $\mathrm{GMT}=$ Geometric mean titer 
Table 2 Immunogenicity of SE and RE before UV-irradiation, as shown by titer ratio of ELISA/N and ELISA/HI

\begin{tabular}{|c|c|c|c|c|c|c|c|c|}
\hline \multirow{2}{*}{$\begin{array}{c}\text { Serum } \\
\text { No. }\end{array}$} & \multirow{2}{*}{\multicolumn{2}{|c|}{ Immunogen }} & \multicolumn{3}{|c|}{ ELISA/N } & \multicolumn{3}{|c|}{ ELISA/HI } \\
\hline & & & Titer & Mean & GMT & Titer & Mean & GMT \\
\hline $1-1$ & $\mathrm{C} 6 / 36$ & SE & 2.55 & $2.60 \pm 0.40$ & 398 & 1.95 & $2.22 \pm 0.41$ & 166 \\
\hline $1-2$ & & & 3.12 & & & 2.82 & & \\
\hline $1-3$ & & & 2.14 & & & 2.14 & & \\
\hline $1-4$ & & & 2.59 & & & 1.98 & & \\
\hline $2-1$ & $\mathrm{C} 6 / 36$ & $\mathrm{RE}$ & 1.96 & $2.09 \pm 0.17$ & 123 & 1.65 & $1.38 \pm 0.35$ & 24 \\
\hline $2-2$ & & & 2.14 & & & 1.14 & & \\
\hline $2-3$ & & & 2.32 & & & 1.71 & & \\
\hline $2-4$ & & & 1.94 & & & 1.03 & & \\
\hline $3-1$ & BHK21 & $\mathrm{SE}$ & 2.59 & $2.44 \pm 0.22$ & 272 & 2.29 & $2.13 \pm 0.23$ & 134 \\
\hline $3-2$ & & & 2.28 & & & 1.97 & & \\
\hline $4-1$ & BHK21 & $\mathrm{RE}$ & 1.86 & $2.07 \pm 0.31$ & 119 & 1.25 & $1.53 \pm 0.57$ & 34 \\
\hline $4-2$ & & & 2.26 & & & 1.97 & & \\
\hline $4-3$ & & & 2.52 & & & 2.21 & & \\
\hline $4-4$ & & & 1.99 & & & 0.78 & & \\
\hline $4-5$ & & & 1.76 & & & 1.45 & & \\
\hline
\end{tabular}

Table 3 Statistical analysis on N, ELISA and HI titer and titer ratio differences raised by $\mathrm{SE}$ and RE before UV-irradiation

\begin{tabular}{llc}
\hline Immunogens & $\begin{array}{l}\text { log titer and } \\
\text { titer ratio }\end{array}$ & $\mathrm{P}$ value \\
\hline $\mathrm{SE}$ and $\mathrm{RE}$ of $\mathrm{C} 6 / 36$ & $\mathrm{~N}$ & $0.02<\mathrm{P}<0.05$ \\
& $\mathrm{ELISA}$ & $>0.10$ \\
& $\mathrm{HI}$ & $0.02<\mathrm{P}<0.05$ \\
& $\mathrm{ELISA} / \mathrm{N}$ & $>0.10$ \\
& $\mathrm{ELISA} / \mathrm{HI}$ & $0.02<\mathrm{P}<0.05$ \\
$\mathrm{SE}$ and $\mathrm{RE}$ of & $\mathrm{N}$ & $>0.10$ \\
$\mathrm{BHK} 21$ & $\mathrm{ELISA}$ & $0.02<\mathrm{P}<0.05$ \\
& $\mathrm{HI}$ & $>0.10$ \\
& $\mathrm{ELISA} / \mathrm{N}$ & $>0.10$ \\
& $\mathrm{ELISA} / \mathrm{HI}$ & $>0.10$ \\
\hline
\end{tabular}

$\mathrm{RE}$ from $\mathrm{C} 6 / 36$ cells produced similar ELISA titers. In the case of immunogen from BHK21 cells, both SE and RE produced similar N and HI titers, while ELISA titer produced by RE was less than the titer by SE and the difference was statistically significant (Table 3). The antibody titers produced by immunogens from $\mathrm{C} 6 / 36$ and BHK21 cells were almost the same except that $\mathrm{N}$ titer by $\mathrm{SE}$ antigen from $\mathrm{C} 6 / 36$ cells was lower than the titer by other antigens (Table 1). Since immunogens of SE and RE from C6/36 cells and SE from BHK21 cells 
possessed comparable ELISA titers as shown in Table 4, the results may indicate low immunogenicity of SE from $\mathrm{C} 6 / 36$ cells to induce $\mathrm{N}$ antibodies. Lower ELISA titer by RE from BHK21 cells may be explained by its slightly less ELISA titer (Table 4). The antibody titers were compared by their ratios (ELISA/N and ELISA/HI), and the results were shown in Table 2. The SE from C6/36 cells showed higher ELISA/HI ratio than RE from the same cells with statistically significant difference, while other ratios did not show significant difference between $\mathrm{SE}$ and $\mathrm{RE}$. In this series of experiment a high mortality rate of mice around $40 \%$ was observed probably due to encephalitis caused by residual infective virus in the immunogens (data not shown). Therefore, it was conceivable that the antibody titers and their ratios in Tables 1 and 2 might reflect the effect of viral antigens produced in mice after virus replication, besides immunogenicity of inoculated specimens. Therefore, subsequent experiments were performed by immunogens which had been inactivated by UV-irradiation.

\section{Mouse immunogenicity of SE and RE after UV-irradiation}

Each immunogens of SE and RE from C6/36 and BHK21 cells were irradiated by UV as described in the Materials and Methods, and ELISA titers of these immunogens were shown in Table 4. The ELISA titer of SE from both C6/36 and BHK21 cells was reduced around $78 \%$, while the titer reduction of RE was less (around $42-43 \%$ ).

The antibody titers of individual mouse serum raised by UV-inactivated immunogens were shown in Table 5. Only the HI titer produced by RE from BHK21 cells was higher than the titer by SE from the same cell, and the difference was statistically significant (Table 7).

The titer ratio (ELISA/N and ELISA/HI) of the individual mouse serum was shown in Table 6 . In this case, only the ELISA/HI produced by SE from $\mathrm{C} 6 / 36$ cells was higher than the titer by RE from the same cells, and the difference was statistically significant.

\section{Comparison of the immunogenicity before and after UV-irradiation}

The effect of UV-irradiation on the immunogen was evaluated by comparing the antibody titers (N, ELISA, HI) as well as their ratios (ELISA/N, ELISA/HI) raised by each immunogen before and after UV-irradiation. The statistically significant difference was observed only for the reduction in $\mathrm{HI}$ titer produced by $\mathrm{RE}$ from $\mathrm{C} 6 / 36$ cells and the increase in ELISA/N ratio produced by RE from BHK21 cells (Table 8). Other immunogenicities were apparently not affected by UV-irradiation.

Table 4 ELISA titer of immunogens before and after UVirradiation

\begin{tabular}{lcccc}
\hline \multirow{2}{*}{ Immunogen } & \multicolumn{2}{c}{ ELISA titer of immunogen } & \multirow{2}{*}{$\begin{array}{c}\text { Reduction } \\
\text { in ELISA titer }\end{array}$} \\
\cline { 3 - 4 } & & before UV & after UV & \\
\hline C6/36 & SE & 232 & 50 & 78.45 \\
C6/36 & RE & 206 & 116 & 43.69 \\
BHK21 & SE & 229 & 50 & 78.15 \\
BHK21 & RE & 186 & 107 & 42.48 \\
\hline
\end{tabular}


Table 5 Immunogenicity of SE and RE after UV irradiation, as shown by titers in $\log$ for N, ELISA and HI

\begin{tabular}{|c|c|c|c|c|c|c|c|c|}
\hline \multirow{2}{*}{$\begin{array}{c}\text { Serum } \\
\text { No. }\end{array}$} & \multirow{2}{*}{\multicolumn{2}{|c|}{ Immunogen }} & \multicolumn{2}{|r|}{$\mathrm{N}$} & \multicolumn{2}{|r|}{ ELISA } & \multicolumn{2}{|r|}{$\mathrm{HI}$} \\
\hline & & & Titer & Mean & Titer & Mean & Titer & Mean \\
\hline $1-1$ & \multirow[t]{5}{*}{$\mathrm{C} 6 / 36$} & \multirow[t]{5}{*}{ SE } & 2.20 & \multirow{5}{*}{$\begin{array}{l}1.54 \pm 0.54 \\
(\mathrm{GMT} 35)\end{array}$} & 4.58 & \multirow{5}{*}{$\begin{array}{c}4.42 \pm 0.20 \\
(\mathrm{GMT} 26,302)\end{array}$} & 1.90 & \multirow{5}{*}{$\begin{array}{l}1.96 \pm 0.13 \\
(\mathrm{GMT} 91)\end{array}$} \\
\hline $1-2$ & & & 1.00 & & 4.58 & & 1.90 & \\
\hline $1-3$ & & & 1.00 & & 4.11 & & 1.90 & \\
\hline $1-4$ & & & 1.90 & & 4.48 & & 2.20 & \\
\hline $1-5$ & & & 1.60 & & 4.35 & & 1.90 & \\
\hline $2-1$ & \multirow[t]{4}{*}{$\mathrm{C} 6 / 36$} & \multirow[t]{4}{*}{$\mathrm{RE}$} & 2.20 & \multirow{4}{*}{$\begin{array}{l}1.98 \pm 0.29 \\
\text { (GMT 95) }\end{array}$} & 4.29 & \multirow{4}{*}{$\begin{array}{c}4.40 \pm 0.17 \\
(\mathrm{GMT} 25,118)\end{array}$} & 2.51 & \multirow{4}{*}{$\begin{array}{l}2.28 \pm 0.29 \\
(\text { GMT } 191)\end{array}$} \\
\hline $2-2$ & & & 2.20 & & 4.23 & & 1.90 & \\
\hline $2-3$ & & & 1.90 & & 4.51 & & 2.20 & \\
\hline $2-4$ & & & 1.60 & & 4.58 & & 2.51 & \\
\hline $3-1$ & \multirow[t]{5}{*}{ BHK21 } & \multirow[t]{5}{*}{$\mathrm{SE}$} & 2.20 & \multirow{5}{*}{$\begin{array}{l}1.84 \pm 0.39 \\
(\text { GMT } 69)\end{array}$} & 4.64 & \multirow{5}{*}{$\begin{array}{c}4.43 \pm 0.23 \\
(\mathrm{GMT} 26,915)\end{array}$} & 2.51 & \multirow{5}{*}{$\begin{array}{l}2.20 \pm 0.22 \\
(\mathrm{GMT} 158)\end{array}$} \\
\hline $3-2$ & & & 1.60 & & 4.51 & & 1.90 & \\
\hline $3-3$ & & & 1.30 & & 4.61 & & 2.20 & \\
\hline $3-4$ & & & 2.20 & & 4.35 & & 2.20 & \\
\hline $3-5$ & & & 1.90 & & 4.08 & & 2.20 & \\
\hline $4-1$ & \multirow{4}{*}{\multicolumn{2}{|c|}{ BHK21 RE }} & 1.90 & \multirow{4}{*}{$\begin{array}{l}1.90 \pm 0.24 \\
(\mathrm{GMT} 79)\end{array}$} & 4.35 & \multirow{4}{*}{$\begin{array}{c}4.50 \pm 0.12 \\
(\mathrm{GMT} 31,622)\end{array}$} & 2.51 & \multirow{4}{*}{$\begin{array}{r}2.66 \pm 0.39 \\
(\mathrm{GMT} 457)\end{array}$} \\
\hline $4-2$ & & & 1.90 & & 4.58 & & 3.11 & \\
\hline $4-3$ & & & 2.20 & & 4.44 & & 2.20 & \\
\hline $4-4$ & & & 1.60 & & 4.61 & & 2.81 & \\
\hline
\end{tabular}

\section{Discussion}

From the results of our immunological studies it appears that the SE of JE virus is immunogenic in mice to induce N, ELISA and HI antibodies, and the immunogenicity of both antigens, SE and RE, were almost comparable. Although UV-irradiation totally inactivated infectivity and partially destroyed ELISA antigenicities in both SE and RE, they still retained their immunogenicities. The different UV-susceptibility of ELISA antigenicity between SE and RE from both $\mathrm{C} 6 / 36$ and BHK21 cells may be explained by different target size of the particle. The RE is the complete virion and possesses larger size and greater number of repetitive epitope units than $\mathrm{SE}$, which is smaller size with less number of repetitive units. It is reasonable to imagine that RE with larger number of repetitive ELISA antigenic epitopes is more resistant to UV-irradiation than SE. Kimura-Kuroda and Yasui (1983) reported that at least five topographically distinct antigenic determinants including N, HI, and ELISA epitopes, were present on $\mathrm{E}$ protein and the epitopes of $\mathrm{HI}$ and $\mathrm{N}$ were separated from each other by monoclonal antibodies.

Recently, Mason et al. (1991) reported that the JE vaccinia virus recombinants possessing JE virus cDNA inserts produced particulate form of antigen containing $\mathrm{M}$ (membrane) and $\mathrm{E}$ proteins of $\mathrm{JE}$ virus. The antigen migrated in sucrose gradients slower than the complete virion, similar to the SE, and induce high level of anti-JE $\mathrm{N}$ antibodies and conferred protection against lethal JE virus infection. 
Table 6 Immunogenicity of SE and RE after UV-irradiation, as shown by titer ratio of ELISA/N and ELISA/HI

\begin{tabular}{|c|c|c|c|c|c|c|c|c|}
\hline \multirow{2}{*}{$\begin{array}{c}\text { Serum } \\
\text { No. }\end{array}$} & \multirow{2}{*}{\multicolumn{2}{|c|}{ Immunogen }} & \multicolumn{3}{|c|}{ ELISA/N } & \multicolumn{3}{|c|}{ ELISA/HI } \\
\hline & & & Titer & Mean & GMT & Titer & Mean & GMT \\
\hline $1-1$ & $\mathrm{C} 6 / 36$ & SE & 2.38 & $2.88 \pm 0.47$ & 758 & 2.68 & $2.46 \pm 0.21$ & 288 \\
\hline $1-2$ & & & 3.58 & & & 2.68 & & \\
\hline $1-3$ & & & 3.11 & & & 2.21 & & \\
\hline $1-4$ & & & 2.58 & & & 2.28 & & \\
\hline $1-5$ & & & 2.75 & & & 2.45 & & \\
\hline $2-1$ & $\mathrm{C} 6 / 36$ & $\mathrm{RE}$ & 2.09 & $2.45 \pm 0.46$ & 281 & 1.78 & $2.12 \pm 0.25$ & 131 \\
\hline $2-2$ & & & 2.03 & & & 2.33 & & \\
\hline $2-3$ & & & 2.61 & & & 2.31 & & \\
\hline $2-4$ & & & 2.98 & & & 2.07 & & \\
\hline $3-1$ & BHK21 & $\mathrm{SE}$ & 2.44 & $2.60 \pm 0.50$ & 398 & 2.13 & $2.23 \pm 0.28$ & 170 \\
\hline $3-2$ & & & 2.91 & & & 2.61 & & \\
\hline $3-3$ & & & 3.31 & & & 2.41 & & \\
\hline $3-4$ & & & 2.15 & & & 2.15 & & \\
\hline $3-5$ & & & 2.18 & & & 1.88 & & \\
\hline $4-1$ & BHK21 & $\mathrm{RE}$ & 2.45 & $2.59 \pm 0.32$ & 389 & 1.84 & $1.84 \pm 0.31$ & 69 \\
\hline $4-2$ & & & 2.68 & & & 1.47 & & \\
\hline $4-3$ & & & 2.24 & & & 2.24 & & \\
\hline $4-4$ & & & 3.01 & & & 1.80 & & \\
\hline
\end{tabular}

Table 7 Statistical analysis on N, ELISA and HI titer and titer ratio differences raised by SE and RE after UV-irradiation

\begin{tabular}{llc}
\hline Immunogens & $\begin{array}{l}\text { log titer and } \\
\text { titer ratio }\end{array}$ & P value \\
\hline SE and RE of C6/36 & $\mathrm{N}$ & $>0.10$ \\
& ELISA & $>0.10$ \\
& HI & $>0.10$ \\
& ELISA/N & $>0.10$ \\
& ELISA/HI & $0.02<\mathrm{P}<0.05$ \\
SE and RE of BHK21 & $\mathrm{N}$ & $>0.10$ \\
& ELISA & $>0.10$ \\
& HI & $0.02<\mathrm{P}<0.05$ \\
& ELISA/N & $>0.10$ \\
& ELISA/HI & $>0.05$ \\
\hline
\end{tabular}


Table 8 Statistical analysis on the difference in antibody titers and titer ratios obtained by immunogens before and after UV-irradiation

\begin{tabular}{lccccc}
\hline \multirow{2}{*}{ Immunogens } & \multicolumn{5}{c}{$\mathrm{P}$ value } \\
\cline { 2 - 6 } & $\mathrm{N}$ & ELISA & HI & ELISA/N & ELISA/HI \\
\hline SE of C6/36 & $>0.10$ & $>0.10$ & $>0.10$ & $>0.10$ & $>0.10$ \\
RE of C6/36 & $>0.10$ & $>0.10$ & $<0.001$ & $>0.10$ & $>0.10$ \\
SE of BHK21 & $>0.10$ & $>0.10$ & $>0.10$. & $>0.10$ & $>0.10$ \\
RE of BHK21 & $>0.10$ & $>0.10$ & $>0.10$ & $0.02<\mathrm{P}<0.05$ & $>0.10$ \\
\hline
\end{tabular}

At present, inactivated JE vaccine has been manufactured from infected mouse brain homogenates, by purifying formaline-inactivated complete virion using primarily ultracentrifugation (Takaku et al., 1968). Till now, little or no attention has been paid for the recovery of SE during JE vaccine preparation, and most of the SE would have been lost in the supernatant of ultracentrifugation. It would be worthwhile to consider the immunogenicity of $\mathrm{SE}$ in the crude vaccine preparation before ultracentrifugation in order to recover more immunogens.

Some flaviviruses have been shown to produce slowly sedimenting antigen along with rapidly sedimenting antigen or complete virion in the mouse brain homogenates or in tissue culture system (Igarashi et al., 1963; Smith et al., 1970; Shameem et al., 1989). This information has permitted us to predict that some form of 'incomplete virion' is synthesized in the early period of replication of JE virus. In the case of dengue type 2 virus, another important member of flavivirus, Cardiff et al. (1971) argued that most of the incomplete virus or top component was associated with several unrelated phenomena, viz. defective interfering particles, adsorbing interfering particles, pleomorphic aggregates of coat structures, macromolecular capsid precursors and some naturally occurring particles which morphologically resemble infectious form except that they did not contain no core structure. Alternatively, $\mathrm{SE}$ may represent a protein synthesized during the course of viral replication which might be released into the medium, besides complete virion, sharing several biological properties possessed by envelope glycoprotein E.

\section{ACKNOWLEDGMENTS}

I would like to express my heart felt thanks to Professor Akira Igarashi for his painstaking support, keen interest and critical reading and comments of the manuscript. A part of this work was supported by a Grant-in-aid for Scientific Research from the Ministry of Education, Science and Culture of Japan, No. 61480161 in the year of 1989-90. The animal experiment was performed in the Animal Research Center for Infectious Tropical Diseases, Institute of Tropical Medicine, Nagasaki University. Special thanks are due to Drs. K. Morita and S. Matsuo and all the staff members of this department for their co-operation through out the whole period of my research work. 


\section{REFERENCES}

1 ) Calisher, C.H., Karabatsos, N., Dalrymple, J.M., Shope, R.E., Porterfield, J.S., Westaway, E.G. and Brandt, W.E. (1989): Antigenic relationships between flaviviruses as determined by cross neutralization tests with polyclonal antisera, J. Gen. Virol., 70, 37-43

2) Cardiff, R.D., Brandt, W.E., McCloud, T.G., Sapiro, D. and Russell, P.K. (1971): Immunological and biophysical separation of dengue-2 antigens, J. Virol., 7, 15-23

3 ) Clarke, D.H. and Casals, J. (1958): Techniques for hemagglutination and hemagglutinationinhibition with arthropod-borne viruses, Am. J. Trop. Med. Hyg., 7, 561-573

4 ) Eagle, H. (1959): Amino acid metabolism in mammalian cell cultures, Science, 130, 432-437

5) Hammon, W. McD., Kitaoka, M. and Downs, W.G. (eds.) (1971): Immunization for Japanese encephalitis, Igaku-shoin, Tokyo

6) Hashimoto, N., Yamada, K. and Kanamitsu, M. (1971): A microtiter method for assay of neutralizing antibodies against group B arboviruses, Virus, 21, 55-59

7 ) Hori, H., Morita, K. and Igarashi, A. (1986): Oligonucleotide fingerprint analysis of Japanese encephalitis virus strains isolated in Japan and Thailand, Acta Virol., 30, 353-359

8 ) Huang, C.H. (1982): Studies of Japanese encephalitis in China, Adv. Virus Res., 27, 71-101

9) Igarashi, A., Kitano, H. and Fukai, K. (1963): Heterogenicity in hemagglutinating agent of Japanese B encephalitis virus, Biken J., 6, 25-26

10) Igarashi, A. (1978): Isolation of Singh's Aedes albopictus cell clone sensitive to dengue and chikungunya viruses, J. Gen. Virol., 40, 531-544

11) Igarashi, A., Bundo, K., Matsuo, S. and Lin, W.J. (1981): Enzyme-linked immunosorbent assay (ELISA) on Japanese encephalitis virus. I. Basic condition of the assay of human immunoglobulin, Trop. Med., 23, 49-53

12) Igarashi, A. (1988): Development of the second generation Japanese encephalitis (JE) vaccine, South East Asian J. Trop. Med. Publ. Hlth., 9, 493-500

13) Kitaoka, M. and Nishimura, C. (1985): Infectious, hemagglutinating, and complement-fixing components in suckling mouse brains infected with Japanese encephalitis virus, Jpn. J. Med. Sci. Biol., 18, 177-187

14) Kuroda-Kimura, J. and Yasui, K. (1983): Topographical analysis of antigenic determinants on envelope glycoprotein V3 (E) of Japanese encephalitis virus, using monoclonal antibodies, J. Virol., 45, 124-132

15) Mason, P.W., Pincus, S., Fournier, M.J., Mason, T.L., Shope, R.E. and Paoletti, E. (1991): Japanese encephalitis virus-vaccinia recombinants produce particulate forms of the structural membrane proteins and induce high levels of protection against lethal JEV infection, Virology, 180, $294-305$

16) Morita, K., Bundo, K. and Igarashi, A. (1982): Enzyme-linked immunosorbent assay (ELISA) on Japanese encephalitis virus. IV. A computer system to calculate ELISA end point titer from ELISA-OD at a single dilution of test sera, Trop. Med., 24, 131-137

17) Oya, A. (1988): Japanese encephalitis vaccine, Acta Paediatr. Jpn., 30, 175-184

18) Shameem, G.M.M., Morita, K., Bundo-Morita, K. and Igarashi, A. (1989): Production of slowly sedimenting and rapidly sedimenting components associated with Japanese encephalitis virus envelope glycoprotein E in infected cell culture fluids, Trop. Med., 31, 111-123

19) Smith, T.J., Brandt, W.E., Swanson, J.L., McCown, J.M. and Buescher, E.L. (1970): Physical and biological properties of dengue-2 virus and associated antigens, J. Virol., 5, 524-532

20) Srivastava, A.K., Aira, Y., Mori, C., Kobayashi, Y. and Igarashi, A. (1987): Antigenicity of Japanese encephalitis virus envelope glycoprotein V3 (E) and its cyanogen bromide cleaved fragments examined by monoclonal antibodies and Western blotting, Arch. Virol., 96, 97-107

21) Takaku, K., Yamashita, T., Osanai, T., Yoshida, I., Kato, M., Goda, H., Takagi, M., Hirota, 
T., Amano, T., Fukai, K., Kunita, N., Inoue, K., Shoji, K., Igarashi, A. and Ito, T. (1968): Japanese encephalitis purified vaccine, Biken J., 11, 25-39

22) Umenai, T., Krzysko, R., Bektimirov, A. and Assaad, F.A. (1985): Japanese encephalitis: current world wide status, Bull. WHO, 63, 625-631

23) Voller, A., Bidwell, O. and Bartlet, A. (1976): Microplate enzyme immunoassay for the immunodiagnosis of viral infections. pp. 506-512. In N.R. Friedman (ed.) Manual for Clinical Immunology, American Society for Microbiology, Washington, D.C. 